sasági megbízottak segítségével, valamint az ún. dekoncentrált intézményekkel igyekezett az önkormányzatok hatalmát, befolyását korlátozni, vagy élesebben fogalmazva: megkezdte az önkormányzatok bekeritését.

Az ellenzéki pártok - mindenekelớtt az SZDSZ - viszont kezdettól fogva fölkarolta az önkormányzatokat, támogatta tevékenységüket, $\mathrm{s}$ ha kellett, védelmükre kelt. Nagyon gyorsan kialakult az új helyi hatalom struktúrája, amelyben meggyengült megyék, kormánypárti köztársasági megbízottak és dekoncentrált szervezetek, valamint jobbára ellenzéki (vagy független) önkormányzatok múködnek, $\mathrm{s}$ vívják sajátos hatalmi harcukat. A tét egyszerúen az, hogy a nemrég alakult önkormányzatiság nem esik-e áldozatául az új államerôsítoó, centralizációs törekvéseknek. A nagypolitika szemmel láthatóan fölismerte az önkormányzatokban rejlổ politikai lehetôséget, $\mathrm{s}$ azt a maga javára szeretné kihasználni. Természetesen érthető módon.

A választás tapasztalatait természetesen még hosszan lehetne sorolni. Úgy gondolom, hogy a folytatás nem marad el; különösen a hamarosan sorra kerülổ választások elókészületeiben lehet majd az elsố szabad választás tanulságait felhasználni. Kötetünk ehhez minden bizonnyal segítséget nyújt. Ezért is szeretném mindazoknak a figyelmébe ajánlani, akik aktívan foglalkoznak helyi vagy országos politikával, s azoknak akik érdeklődnek a politikai szociológia iránt; oktatják, tanulják vagy tudományos kutatásaikban múvelik a politológiát.

Bốhm Antal

\title{
AZ ALKALMAZOTT SZOCIÁLGEOGRÁFIA ELMÉLETI ÉS MÓDSZERTANI KÉRDÉSEI
}

Berényi István

Budapest, 1992. Akadémiai Kiadó, 165 o.

Földrajzi Tanulmányok 22.

Sorozatszerkesztố: Marosi Sándor

Berényi István több évtizedes kutatói munkásságának egyik jelentốs rész-összefoglalója az akadémiai doktori értekezése nyomán készült könyv, s ez már szinte elốlegezi a munka értékét, hiszen már ,átment a legmagasabb minôsítô fórum megméretésén".

A szociálgeográfia elmélete és módszere

A tanulmány egyik nagy érdeme, hogy szinte teljeskörúen feltárja és a szélesebb szakmai közvélemény számára is újdonsággal szolgáló módon elemzi a szociálgeográfia kialakulásának és fejlôdésének összefüggésrendszerét, társadalmi és tudományos hátterét. Teleki Pál tudománytörténeti megközelítését alkalmazza Berényi István akkor, amikor nemcsak a könyvészeti fejlôdés szemléltetésére, hanem a "gondolat fejlődésére" helyezi a fő hangsúlyt.

Az emberföldrajz a XIX. század közepétól kezdve formálódó gondolatrendszerén belül egyszerre több irányzat jelent meg, s ezek az irányzatok nemzeti (francia, német) sajátosságokat öltöttek, késôbb pedig az angolszász 
megközelítések megjelenése hozott jelentổs újításokat.

Berényi István részletesen felsorolja és értelmezi az egyes irányzatok földrajzelméleti összefüggéseit, bemutatja az alkalmazott földrajz szempontjából számbavehetổ értékeiket, s korlátaikat.

A fejezet számomra egyetlen, kisebb hiányossága, hogy a szociálgeográfia magyarországi fejlổése csak periférikusan jelenik meg, pedig úgy ítélem meg, hogy a magyar földrajztudományban a szociálgeográfiai nézốpont rendkívül korán megjelent, sốt egy kevéssé ismert magyar szociológus-geográfus, Dékány István, már a XX. század második évtizedétôl kezdve mélyreható tudományelméleti és módszertani kutatásokat is végzett, s kísérletet tett a német Anthropogeographie és a francia Géographie Sociale szintézisének megteremtésére, a szociogeográfia, a kultúrföldrajz, a szociográfia, a szociológia kapcsolati rendszerének tisztázására.

Az alkalmazott szociálgeográfia elmélete és módszere

Az alapkutatás jellegũ szociálgeográfiai elemzésekkel párhuzamosan igény merült fel ezek gyakorlatban történô értelmezésére és alkalmazására is, $\mathrm{s}$ így formulázódott meg az alkalmazott szociálgeográfia, melynek célja a funkcionális térszerkezet és a társadalmi struktúra tér-idố kapcsolatában kialakuló konfliktusok feltárása és értékelése, az alapfunkciók fejlesztésébe és térbeli rendjébe a lokális és csoportspecifikus társadalmi elvárások beépítése.

Berényi István felfogásában az alkalmazott szociálgeográfia nem tartalmában és alapvetố célkitưzéseiben tér el az alapkutatásokban megfogalmazott tételektôl, hanem abban, hogy a tér-gazdaság-társadalom összefüggésrendszereinek konfliktusaira összpontosít an- nak érdekében, hogy a központi, regionális és lokális érdekek a tervezés során tudományos megalapozottsággal ütközzenek és jussanak kifejezésre. Az alkalmazott szociálgeográfia a tervezés tudományos megalapozásában való részvételen túl közremüködik a terv megvalósításában, s a megvalósult tervek társadalmi konzekvenciáinak feltárásában is.

\section{Alkalmazott szociálgeográfiai kutatások}

E világos feladatmeghatározás és feladatvállalás teszi lehetôvé Berényi István számára, hogy a részletkutatásokban mindvégig megmaradjon a tudomány általa elfogadott keretei között, s az alkalmazott szociálgeográfiai kutatások ne váljanak a korszak elvárásainak megfelelően alkalmazkodó kutatásokká.

Berényi István terepkutatásainak egyik figyelemreméltó összetevôje, hogy tudatosan vállalta fel a két világháború között szociográfiai módszerekkel kutatott települések (Tard, Királyhegyes), és a korábban érdemben nem kutatott települések (Bélapátfalva, Tiszakécske) részben párhuzamos és összehasonlító vizsgálatát.

Tard és Királyhegyes kapcsán nyomon tudjuk követni a több évtizedes átalakulás összetevôit, a települési tér és társadalom egyfajta folytonosságát, stabilitását, $\mathrm{s}$ részben a szerves fejlốdést megtörô diszfunkcionális elemek hatásait. A tanulmány rendkívül értékes részét képezi a települési mikroterek feltárása és szemléltetése.

Bélapátfalva és Tiszakécske helyzete sok vonatkozásban eltérố, de közös elemként fogalmazhatjuk meg, hogy a szocialista átalakítás mindkét települést rendkívül sajátosan érintette. Bélapátfalva esetében szinte modellszerũ a szocialista iparosítás következményeinek, mikrotársadalmi és mikrotérségi hatásainak elemzése, míg Tiszakécske elsớdlegesen abból a szempontból érdemel figyelmet, hogy 
hogyan tudott egy agrártelepülés, mely térbeli helyzetében, történeti fejlôdésében rendkívül sok egyedi sajátosságot mutatott, beleilleszkedni az adott politikai, gazdasági, társadalmi elvárások rendszerébe, s ezeknek milyen következményei voltak a belsố települési és társadalmi-gazdasági szerkezetre. A személyi pályák rendkívül differenciáltan jelennek meg az elemzésben, de egy személyi tragédia nyilván nem szociálgeográfiai kérdés...

\section{Szociálgeográfiai alapfogalmak}

Berényi István kötetének fontos és szerencsés része az általa használt szociálgeográfiai fogalmak rövid, definíciószerú közlése és német megfelelốik feltüntetése. Ezzel vállalja is saját ,,iskola-elkötelezettségét." Úgy gondolom, hogy aki diszciplina-alapozó kutatásokra és kutatási eredményeinek mások által történổ megértésére és követésére tart igényt a jövốben követheti e tekintetben is Berényi István vállalkozását.
Értékes, gondolkodásra késztetô kötet

Berényi István ,,magánkutatásként” indult kutatási témája kifutott és beérett, s hivatkozásaiból is láthatóan iskolát teremtett maga körül. Vannak a kötetnek olyan megállapításai, melyekkel vitába lehet, $\mathrm{s}$ nyilván vitába is fognak szállni. Ez nem kisebbíti, hanem növelheti a kötet értékét, mert valószínúleg nem érdemes olyan munkákat publikálni, melyek nem indítanak el új gondolatokat, nem gerjesztenek vitát és hatást.

Számomra a mũ figyelemre méltó értéke, egyben tanulsága és élménye is az, hogy lényegét tekintve visszaigazolta és új módszerekkel megerôsítette Dékány István 1921-es megfogalmazását: ,,A társadalom szerkezete alig mondható földrajzi úton meghatározónak, mégis földrajzi alapon kell kiindulnunk."

Berényi István könyvét jó szívvel ajánlom szociológusok, geogråfusok, közgazdászok, tervezók, településtudományi és igazgatási szakemberek figyelmébe, s meggyốzôdésem, hogy haszonnal forgathatják, új gondolatokat és szemléletet meríthetnek belóle. 